\title{
A IMAGEM SAGRADA NA ERA DA REPRODUTIBILIDADE TÉCNICA: SOBRE SANTINHOS*
}

\author{
Renata de Castro Menezes \\ Museu Nacional/Universidade Federal do Rio de Janeiro - Brasil
}

Resumo: Os santinhos são retângulos de papel cujas faces comportam, de um lado, uma imagem de santo (ou santa, ou santos), e, do outro, textos em que se combinam preces e prescrições para utilizá-las corretamente, detalhes da vida do santo, propaganda da gráfica que imprime o material, etc. Em meu artigo procuro trazer algumas reflexões sobre as formas de interação (religiosa ou não) que podem se dar em torno desse compósito texto-imagem, tais como percebidas ao acompanhar sua circulação em trabalho de campo, e uma discussão da simbologia que a eles pode estar associa$d a$, a partir de uma interpretação de textos e imagens.

Palavras-chave: catolicismo, culto aos santos, materialidade da devoção, religião e objetos.

Abstract: Santinhos (holy cards, or prayer cards) are small rectangular pieces of paper with a picture of a saint (or several saints) on one side and text on the other: the latter combines prayers and instructions for correct use of the card, details of the saint's life, advertising for the printing house that made the card, and so on. In this article I intend to explore various forms of interaction (religious and otherwise) involving this text-image composite, including those observed during my field research, and a discussion of the symbology frequently associated with the cards, based on an interpretation of both the texts and the images.

Keywords: Catholicism, cult of the saints, materiality of devotion, religion and objects.

* Versões preliminares deste artigo foram apresentadas e debatidas em distintos eventos organizados pelos professores Maria Laura Viveiros de Castro Cavalcanti (IFCS/UFRJ), Aparecida Vilaça (Museu Nacional/UFRJ) e Edmundo Pereira (DAN/UFRN). Comentários estimulantes surgiram ainda do professor Fernando Rabossi (IFCS/URFJ). A todos, o meu agradecimento. 


\section{Introdução: materialidades da devoção}

Durante uma viagem a Santiago de Compostela, em julho de 2009, visitei, no seminário arquidiocesano de San Martiño Pinario, uma exposição intitulada "A Imprensa e o Santuário", que demonstrava o impacto do desenvolvimento das técnicas gráficas no material sobre a devoção ao próprio São Tiago. A exposição deixava claro que a invenção da imprensa na era moderna possibilitara a reprodução, para além da Bíblia, de uma literatura cristã especificamente católica, como catecismos, livros de orações, devocionários, manuais de liturgia, pronunciamentos de sacerdotes e guias de peregrinação. Havia também em exposição diferentes técnicas de reprodução da imagem, utilizadas na multiplicação de estampas dos santos e dos templos, como a xilografia, a calcografia e a litografia, ${ }^{1}$ formas artesanais de estamparia, substituídas paulatinamente nos últimos anos do século XIX por métodos industriais, ligados à fotografia, que permitiram a multiplicação de imagens em escala ainda maior.

A exposição estabelecia uma perspectiva curiosa, pois o senso comum em mim introjetado estava acostumado a pensar na conexão imprensaescrita-protestantismo. Mas a conexão imprensa-imagem-catolicismo, ali demonstrada, também apontava para rendimentos interessantes, a meu ver

\footnotetext{
Xilografia: "O processo xilográfico consiste em entalhar linhas sobre uma prancha de madeira, pensando que as partes visíveis serão as que estiverem em relevo e que as sem impressão serão as que estarão em baixo relevo." (Xilografia/xilogravura, 2007). Calcografia: "Arte de gravar em metal, que se dá através de vários processos, sendo o mais antigo deles a gravura a buril ou talho-doce, em que a gravação é feita diretamente no metal com um instrumento de aço chamado buril. Outros gêneros da gravura feita em metal, que fazem parte da calcografia, são aqueles conhecidos como água-forte, ponta-seca, águatinta, maneira negra e o verniz mole. $\mathrm{O}$ termo também pode ser usado para nomear o local onde essas impressões são feitas." (Calcografia, 2010). Litografia: "Um método de impressão a partir de imagem desenhada sobre base, em geral de calcário especial, conhecida como 'pedra litográfica'. Após desenho feito com materiais gordurosos (lápis, bastão, pasta etc.), a pedra é tratada com soluções químicas e água que fixam as áreas oleosas do desenho sobre a superfície. A impressão da imagem é obtida por meio de uma prensa litográfica que desliza sobre o papel. A flexibilidade do processo litográfico permite resultados diversos em função dos materiais empregados: em lugar da pedra, cada vez mais são usadas chapas de plástico ou metal, em particular de zinco. O desenho, por sua vez, altera sua fisionomia de acordo com o uso de pena, lápis ou pincel. Testes de cor, texturas, graus de luminosidade e transparência conferem às litografias distintos aspectos." (Litografia, 2010).
} 
ainda pouco explorados pela antropologia. Pois se a literatura sobre a imagem católica é imensa, ${ }^{2}$ pouco se havia indagado sobre as possibilidades abertas ao catolicismo pelo surgimento de técnicas massivas de reprodução da imagem, que baixam custos e facilitam sua circulação.

Uma série de perguntas surgiram em torno das implicações para a imagem devocional advindas do fato de ela poder se multiplicar. As funções proselitistas e pedagógicas das estampas eram quase óbvias, pela divulgação e apresentação dos santos, de seus santuários. Mas poderiam haver outras funções menos óbvias a serem descobertas. Teria a devoção através dessas imagens, ou diretamente a essas imagens, características singulares diante de imagens em outros suportes? Em que concepções "nativas" de agência e poder estariam elas embebidas? Seriam válidas, para as imagens sagradas, as observações de Walter Benjamin (1994) sobre a perda da aura pela reprodução mecânica? Essas questões me pareceram particularmente relevantes porque já estava atenta para um tipo de material encontrado abundantemente na pesquisa de doutorado ${ }^{3}$ e cuja análise gostaria de aprofundar: os santinhos.

Este artigo traz algumas interpretações preliminares sobre esses pequenos objetos de papel, as quais resultam de uma pesquisa, ora em fase inicial, sobre materialidades da devoção, na qual a vida social dos santinhos (Appadurai, 1990; Kopytoff, 1990) é um dos casos analisados. Ressalte-se que, embora relacionado a uma pesquisa inicial, o trabalho é, na verdade, o desdobramento de um largo percurso de estudo com aquilo que é comumente chamado de catolicismo popular ou culto aos santos, mas que considero mais pertinente chamar de antropologia da devoção, para caracterizar uma relação

2 Uma referência exaustiva seria impensável, mas à guisa de exemplos de autores que ressoam no debate atual, cito os trabalhos de Hans Belting (1998, 2007), Serge Gruzinski (2004), Victor Turner (1978), Carlo Ginzburg (2001a, 2001b), David Freedberg (1992) e Michael Herzfeld (1990), dentre outros.

3 A pesquisa "A dinâmica do sagrado" visava analisar as formas de sociabilidade em um santuário católico e estendeu-se de 1999 a 2004, compreendendo um trabalho de campo realizado por mim, no primeiro semestre de 2001, e por uma assistente de pesquisa, Alcina Quintela, no segundo semestre do mesmo ano. Dessa pesquisa resultaram minha tese (Menezes, 2004a) e algumas publicações (Menezes, 2004b; 2004c, 2005, 2009), havendo um desdobramento posterior em outras pesquisas sobre a antropologia da devoção. 
específica que procuro compreender etnograficamente. ${ }^{4}$ Nesse percurso, muitas vezes focalizar a análise em objetos revelou-se um artifício metodológico para abordar a devoção, já que, nessa área, limites óbvios pareciam se impor à observação participante e à entrevista. Pois como se pergunta o indizível ou como se observa o invisível? Muitas vezes é preciso aceder a expressões materiais que visibilizem emoções, entidades, cosmologias, para compreender as relações mais profundas articuladas em torno de elementos de cultura material. A capacidade de condensação de determinados objetos - que concentram ações e significados - torna-os pontos estratégicos para a análise de expressões religiosas.

Assim, ao estudar os santinhos, tento transformar uma série de intuições etnográficas em torno deles numa reflexão sistemática. O que pretendo fazer é um exercício interpretativo, trazendo para o centro da análise pedaços de papel colorido, de caráter aparentemente "residual" ou "periférico", a fim de observar seu rendimento heurístico.

\section{Apresentando os santinhos}

Os santinhos são geralmente pequenos folhetos impressos em off-set, em pedaços de papel couchê $150 \mathrm{~g}$ de cerca de $10 \mathrm{~cm}$ de altura por $5 \mathrm{~cm}$ de largura, compostos, de um lado, pela imagem colorida de um santo ou santa, e, do outro, por um texto, ambos arranjados mais comumente de maneira vertical. Ao longo deste artigo, algumas reproduções de santinhos serão apresentadas para facilitar a compreensão dos argumentos.

4 Em um trabalho anterior, tento apresentar uma definição do que está em jogo nessa distinção: “alguém que se identifica como um devoto não é apenas alguém que recebeu alguma graça de um santo, mas alguém que se envolveu com ele numa relação permanente, vivida, parafraseando o poeta Vinícius de Moraes, como infinita enquanto dure. A devoção envolve não apenas pedidos - graças - agradecimentos, mas um processo de identificação entre o devoto e seu santo, que envolve sentimentos como a amizade, a fé e a confiança, e a certeza da presença constante do santo na vida do devoto. Quem entrou no registro da devoção adquiriu uma chave de interpretação da própria biografia, que passa a ser lida como uma sucessão de intervenções do santo, de graças e proteções que lhe conferirão a felicidade, ainda que esta precise ser norteada pela conformação." (Menezes, 2009, p. 131-132). Para maiores esclarecimentos, creio que a leitura completa desse trabalho pode ser útil.

Horizontes Antropológicos, Porto Alegre, ano 17, n. 36, p. 43-65, jul./dez. 2011 

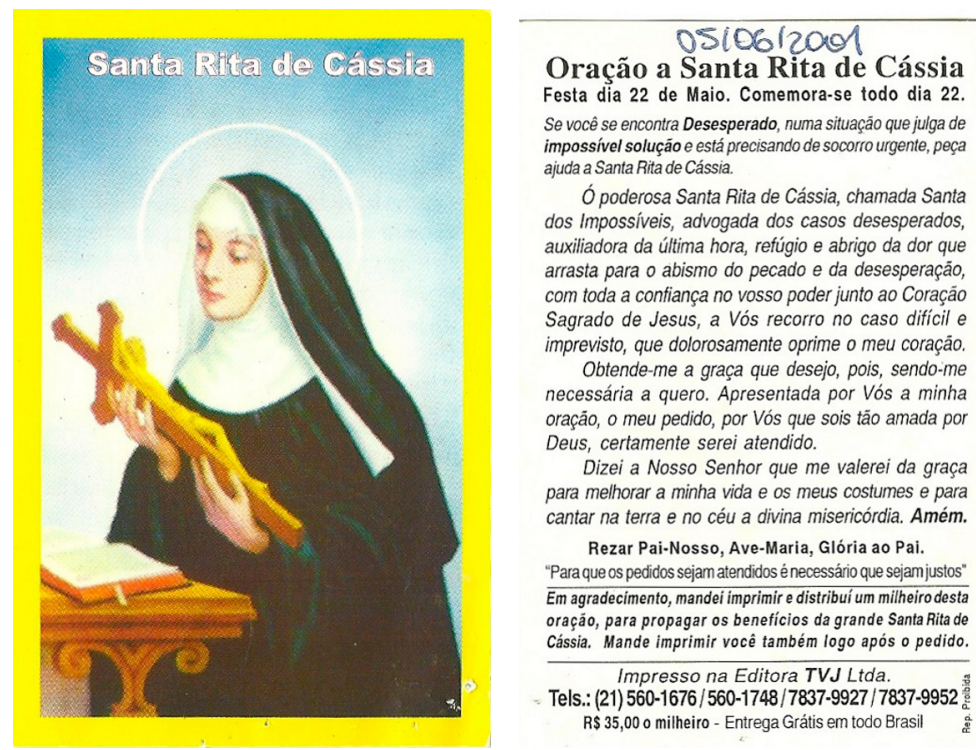

Figuras l e 2. Um santinho de Santa Rita de Cássia, nas faces imagética e textual (uso não comercial, acadêmico, das reproducões).

O conjunto de santinhos sobre o qual vou me deter resulta de coleta em trabalho de campo realizado no convento franciscano de Santo Antônio, no Largo da Carioca, Rio de Janeiro, na pesquisa de doutorado já mencionada. Esse corpus encontra-se atualmente em fase de atualização, tanto através do retorno ao convento, na festa do padroeiro, em 2010, como através da doação de colegas e alunos e ainda por meio de coletas eventuais feitas quando eles aparecem em lugares não religiosos, como, por exemplo, bancas de jornais, consultórios veterinários, floriculturas. Porém, a base para falar deles são (ainda) as referências do convento, obtidas a partir de uma coleta metódica realizada no primeiro semestre de $2001 .^{5}$

\footnotetext{
5 Os santinhos obtidos no convento foram coletados em 28 visitas ali realizadas no primeiro semestre de 2001, a maioria das quais realizada às terças-feiras, dia da semana destinado ao culto de Santo Antônio, quando a movimentação do convento é maior. Mas também coletei material na trezena preparatória da festa do padroeiro e na própria festa, no dia 13 de junho. Caso um santo aparecesse em dois tipos de santinhos diferentes, isto é, representado de maneiras distintas, era recolhido mais de um exemplar no mesmo dia. Para maiores detalhes, ver as discussões metodológicas em Menezes (2004b).
} 


\begin{tabular}{|lc|}
\hline Figura representada & no de vezes em que apareceu \\
Santo Expedito & 32 \\
Nossa Senhora & 10 \\
Jesus & 7 \\
Santo Antônio & 4 \\
São Judas Tadeu & 4 \\
Treze Almas Benditas & 4 \\
Santa Edwiges & 2 \\
Santa Rita de Cássia & 2 \\
Bem-aventurado José Maria Escrivá & 1 \\
Pe. José Kentenich & 1 \\
Santa Bárbara & 1 \\
Santa Luzia (de Viana do Castelo) & 1 \\
Santa Terezinha das Rosas & 1 \\
Santa Terezinha & 1 \\
\hline
\end{tabular}

Quadro 1. Santinhos recolhidos no convento.

Em sua maioria referidos a santas e santos católicos, os santinhos que encontrei no convento representavam figuras relacionadas a um universo mais amplo do que o estritamente canônico, pois incluíam figuras ambíguas, como as treze almas benditas (que além de serem indefinidas, remetem a um sincrético culto às almas), ou personagens ainda não canonizados, mas em campanha por sua canonização à época, como o beato José Maria Escrivá e o Pe. José Kentenich.

Esses santinhos chegavam ao convento depois de um percurso: a maior parte era comprada aos milheiros, em gráficas especializadas, ${ }^{6}$ que possuem páginas na internet para vender esses produtos e fazem sua entrega pelo correio e que, apesar de muitas vezes terem nomes de santo, não têm ligação com a Igreja. É o caso da Gráfica Santana, Gráfica Santo Expedito. Também podem ser impressos por editoras católicas, como Paulinas ou Vozes, mas no trabalho de campo, estes apareceram em quantidade muito menor. Quanto mais católica a editora, isto é, quanto mais próxima à hierarquia religiosa e

6 Os santinhos recolhidos eram produções da Editora Santa Expedito, Editora TVJ, Gráfica Todos os Santos, Gráfica Santana e Editora Paulinas. 
menos autônoma, mais doutrinário o texto da oração, e há uma restrição das figuras apresentadas a santos canonizados ou a beatos, isto é, a personagens cujo culto é oficialmente permitido pela Igreja. Essa proximidade da gráfica à institucionalidade católica, no entanto, não pode ser percebida pelo nome da empresa, pois muitas vezes elas assumem nomes de santo mesmo sendo "laicas": é preciso localizar seus proprietários.

É possível, ainda, comprar os santinhos no próprio convento, em unidades avulsas, tanto na loja de artigos religiosos do local como nos comerciantes ambulantes que ficam na rua, junto a seus portões. Mas além de não serem os mesmos personagens que se encontram nesses diferentes pontos, na venda unitária, o aumento de preço é percentualmente notável: cerca de $2.500 \%$.

A presença dos santinhos no convento dava-se principalmente enquanto $e x-$ voto: alguns visitantes os traziam para o local e aí os deixavam, espalhados em pilhas por diversos pontos periféricos, isto é, com mais discrição e com menor grau de controle por parte das pessoas do convento, como o pagamento de uma promessa, como o agradecimento por uma graça alcançada e/ou como meio de divulgação de uma devoção, para que os interessados os pegassem gratuitamente.

Os santinhos encontrados têm, como já dito, duas faces, uma imagética e outra textual. À combinação de texto e imagem, estou chamando de compósito. Pensar no santinho em termos de compósito é uma tentativa de tratar texto e imagem em relação, como as duas faces da mesma moeda, escapando da armadilha de privilegiar, a priori, um dos dois lados desse material. Em que medida essa intenção inicial será bem-sucedida, creio, é uma dúvida, pois a seguir serão feitas descrições da parte imagética e da parte textual sequencialmente e o investimento de pesquisa em cada uma delas é ainda diferencial. ${ }^{7}$

\section{A face imagética}

Primeiro, a abordagem da fase imagética. A "imagem" contida nos santinhos pode ser um desenho ou a reprodução fotográfica de uma peça de estatutária.

\footnotetext{
A intimidade com a análise da linguagem - escrita, falada, gestual - já resultou, para além de referências na tese (Menezes, 2004a, 2004b) em artigos sobre o pedido escrito aos santos e sobre a benção de Santo Antônio (ver Menezes, 2004c, 2005). A análise das imagens, presente de forma preliminar em Menezes (2004a, 2004b), só agora começa a se intensificar.
} 

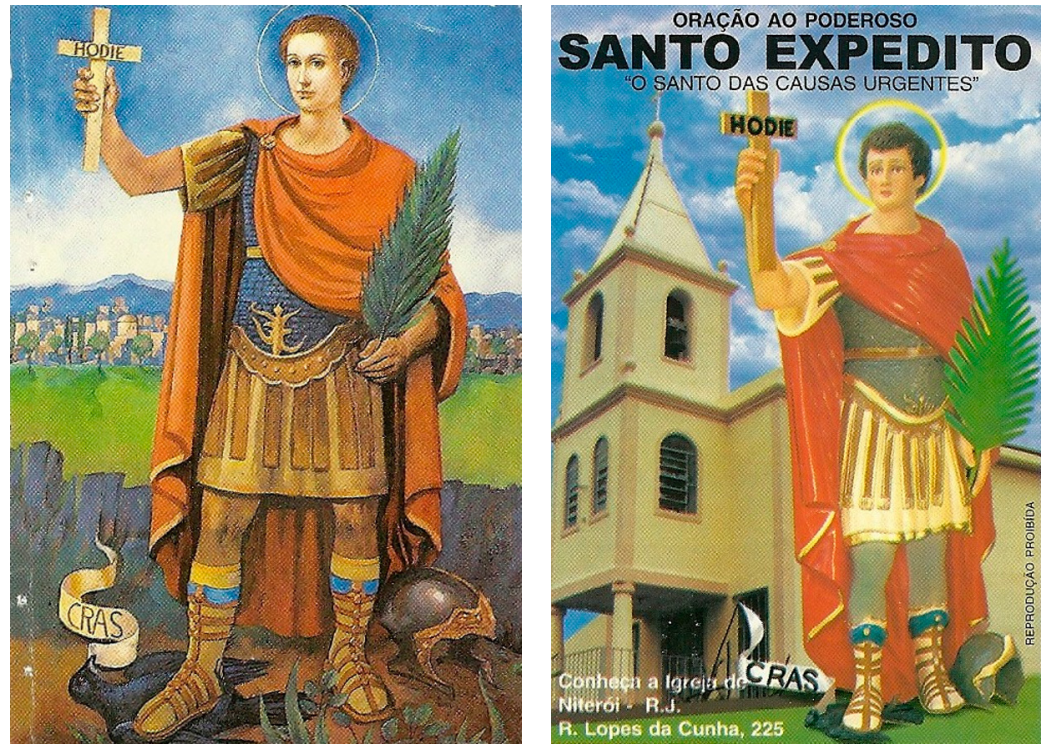

figuras 3 e 4. Santo Expedito em duas formas de representação: em desenho e em fotografia de estatutária (uso não comercial, acadêmico, das reproduções).

A face imagética refere-se a um santo ou a uma santa, ou a conjuntos de santos, representados através de uma certa "estereotipia", cujo caráter seria importante problematizar. $\mathrm{O}$ santinho apresenta uma cena característica do santo a que se refere, a qual está relacionada à sua hagiografia e ao conjunto de legendas e mitos que compõem sua tradição (Certeau, 1990; Jolles, 1976). Pois um santo é uma combinação interessante de história e estória, agregando regimes distintos de verdade que entram em jogo em seu culto (Claverie, 1990; Foucault, 1996). Assim, elementos de aparência física, vestimentas, e atributos como objetos, animais ou instrumentos de martírio, isto é, sinais adicionados à pessoa santa para identificá-la, contribuem nessa configuração.

Algumas imagens trazem atrás de si outras imagens, como aquela de Santo Expedito (Figura 4) que conjuga uma estátua do santo no plano frontal com o templo onde ele é cultuado hoje numa cidade do estado do Rio de Janeiro como pano de fundo, numa sobreposição (ou fusão) de tempos e espaços: o tempo e o espaço do santo e sua cena hagiográfica originária, o tempo e o espaço de seu culto atual. 
O’Neil (1968, p. 963, tradução minha) nos lembra que a iconografia é um tipo de linguagem a ser decodificada, que permite distinguir um santo no panteão católico e que

[...] quando corretamente compreendida, pode revelar muito sobre sua vida, seus atributos e sua devoção. Interpretações mais avançadas podem revelar, também, a postura espiritual e a orientação teológica dos produtores [dessa imagem]. ${ }^{8}$

Ou seja, identificar um santo através de sua imagem implica o manejo de um conjunto de símbolos, como numa linguagem religiosa que se adquire através de uma certa "socialização" e que envolve a habilidade de manipulação de uma série de códigos. Por exemplo, na imagem de Santo Antônio, a seguir (Figura 5), podemos destacar alguns elementos que o caracterizam.

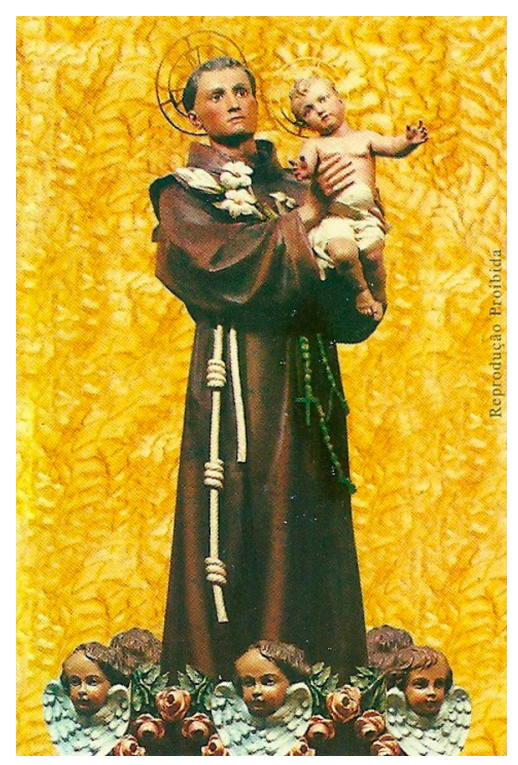

Figura 5. Santo Antônio (de Pádua ou de Lisboa) (uso não comercial, acadêmico, da reprodução).

\footnotetext{
8 No original: "Representations of holy persons became a kind of language, which, when correctly understood, might reveal much about the life, attributes, and devotion to the depicted subject: further interpretation might reveal, as well, the spiritual posture and theological orientation of its makers."
} 
Ao se consultar um dicionário de simbologia católica (Ferguson, 1981) e alguns autores que se detiveram em explicar os sinais diacríticos que caracterizam esse santo, como o próprio O’Neil (1968) acima citado, isto é, ao se recorrer a textos decodificadores, é possível descobrir significados para os vários elementos que fazem parte de sua imagem. A ausência de barba caracteriza um santo que morreu jovem; o tipo de hábito indica a ordem religiosa a qual o santo pertenceu (no caso, franciscana); o cinto de corda com três nós explicita os votos de castidade, obediência e pobreza que os membros dessa ordem professam, o lírio em seus braços indica pureza (sexual); o menino em seus braços é Jesus, que em uma das legendas sobre Santo Antônio lhe teria sido entregue em confiança pela própria Virgem Maria. Pelo ângulo da foto que compõe a estampa, não é possível perceber, mas muito provavelmente, como em outras imagens do santo, o menino deve estar apoiado em um livro que o santo traz nos braços: é um evangelho, ou a Bíblia, sinal de que ele é um teólogo, um doutor da Igreja.

A leitura de todas essas camadas agregadas de significado, no entanto, implica ou um grande grau de conhecimento religioso específico ou, como nesse caso, no recurso a uma bibliografia de apoio, seja no campo litúrgico, seja no campo das artes sacras. Em que medida esses códigos são conhecidos ou manejados, no todo ou em parte, pelos adeptos dessa religião, ou mesmo por alguns de seus sacerdotes? Em campo, vi que a simbologia pode reduzirse a um conjunto de sinais distintivos, sem que seu significado mais amplo seja conhecido. Santo Antônio pode ser então, como ouvi de um interlocutor, simplesmente "o moço sem barba que segura um menino". Estamos diante de níveis de conhecimento diferente, mas também de distinções nos graus de adesão e pertencimento e, mais ainda, diante de diferentes modalidades de relacionamento com os santos: muitas vezes, para um devoto, não é preciso conhecer detalhes biográficos de seu santo protetor para entregar-se a ele. O que é necessário é ser capaz de reconhecê-lo, identificá-lo. O desafio para a continuidade da pesquisa é o de analisar o significado dessas imagens não apenas trabalhando a partir de manuais católicos, ou de dicionários, mas sim recuperando a percepção dos devotos em contextos etnográficos precisos. Pois se o interesse está na variabilidade de processos de simbolização e nos diversos níveis e formas de sociabilidade e de construção de significado, é preciso mapear a diversidade de concepções em torno dos santos e não apenas ater-se aos significados apregoados pela ortodoxia religiosa. 
Alguns santinhos trazem na frente, sobre a imagem, o nome do santo de referência escrito. Como se a imagem não fosse suficiente para a identificação, ou como se não valesse a pena correr o risco do engano. A função de apresentação do santo ao devoto fica assim explicitada. Carlo Ginzburg (2001b) procurará relacionar essa importância da imagem a uma longa tradição cristã de relacionar o texto à visualidade, ressaltando trechos bíblicos em que ações como ver, testemunhar, expor, mostrar, são enfatizadas, dando conotações de profecia sobrenatural ao texto, em suas diferentes e sucessivas traduções.

\section{A face textual}

Quanto à face textual do compósito, ela possui formas mais simples e reduzidas e formas mais complexas e completas. O mínimo de texto que existe em um santinho é uma oração, considerada específica do santo nele representado. Já a forma mais completa era a mais comum de encontrar no convento e também a mais associada a gráficas independentes da Igreja Católica. Voltemos à Figura 2, que apresenta a face textual de um santinho de Santa Rita de Cássia, um bom exemplo da forma mais completa. O texto concentra discursos distintos, apresentados numa estrutura recorrente: na parte superior, há uma inscrição "oração a..." e o nome do santo a que o santinho se refere. Em seguida, pode haver alguns detalhes de sua vida, indicações sobre sua especialidade, a data de sua festa. E pode haver também indicações sobre a situação em que o santo deve ser invocado. No centro da parte textual, e às vezes ocupando sua maior parte, há a oração específica do santo, bem como a indicação da maneira correta de utilizá-la em sua invocação. E geralmente conclui, no rodapé, com a indicação da gráfica em que foi impresso o material. Alguns santinhos trazem ainda explicitamente a referência de que se trata de ex-votos, como o da Figura 2: "Em agradecimento, mandei imprimir e distribuí um milheiro dessa oração, para propagar os benefícios da grande Santa Rita de Cássia."

Sua multivocalidade é evidente, mas os diferentes tipos de discurso que o compõem possuem demarcadores. As mudanças no emissor e receptor da mensagem provocam alteração em pronomes, pessoas e tempos verbais, no vocabulário, no estilo de discurso, enfim - mas as diferenças também são assinaladas por elementos de diagramação: parágrafos, espaçamentos, tamanhos 
de fonte, negritos, itálicos indicam passagens entre os tipos de texto. Assim, a escrita é, num certo sentido, também imagem, pois é possível visualizar as transições de tema pelas mudanças gráficas. ${ }^{9} \mathrm{E}$ se antes vimos que a imagem do santo pode ter seu nome inscrito, numa espécie de afirmação explícita de sua identidade, deve-se perguntar se isso não aponta para uma relatividade na autonomia da interpretação imagem em relação a um texto, a um índice decodificador.

Como já assinalamos, a oração do santo ocupa a parte central da face textual do santinho e está presente em todos eles, mesmo nas formas mais simples. O uso do vocativo - ó minha Santa Rita; ó meu santo Expedito - e da segunda pessoa do plural, vós, pouco usal no português habitualmente falado no Brasil, lembra-nos o quão distante estamos da linguagem do cotidiano, entrando no registro da linguagem sagrada, da prece (Keane, 1997).

As orações geralmente não começam pelo pedido: este vem mais comumente embutido em sua parte média-final, após uma abertura que invariavelmente lança um apelo ao santo, uma súplica. Em vários casos, há também frases e expressões que promovem a humilhação ritual do suplicante, que ressaltam suas fragilidades e necessidades, ampliando a assimetria entre santo e devoto e justificando o pedido - algo que, pela pequenez de quem pede, sem a ajuda do santo seria impossível alcançar. A citação a seguir, extraída da oração de um santinho de Nossa Senhora do Desterro, exemplifica bem o jogo de produção de assimetrias que a combinação hiperbólica de exaltação (do santo) e rebaixamento (do devoto) é capaz de gerar.

[exaltação da santa:] Ó Bem-aventurada Virgem Maria, Mãe de Nosso Senhor Jesus Cristo, Rainha do Céu e da Terra, advogada dos pecadores, auxiliadora dos cristãos, desterradora das indigências, das calamidades, dos inimigos corporais e espirituais, dos maus pensamentos, das cenas terríveis do dia do juízo, das pragas, das bruxarias, dos malfeitores, ladrões, arrombadores, assaltantes e assassinos. [rebaixamento do suplicante:] Minha amada Mãe, eu prostrado agora aos Vossos pés, cheio de arrependimento das minhas pesadas culpas, por

9 Agradeço à colega Bruna Franchetto as referências, em conversa pessoal, sobre as relações entre a percepção da escrita e do grafismo entre os Kuikuro, que inspiraram esse parágrafo. 
Vosso intermédio, imploro perdão ao boníssimo Deus. [apresentação do pedido:] Rogais ao Vosso Divino JESUS, por nossas famílias, para que Ele desterre de nossas vidas todos esses males, nos dê perdão de nossos pecados e que nos enriqueça de sua Divina graça e Misericórdia. Cobri-nos com o Vosso manto maternal e desterrai de todos nós, todos os males e maldições, e em especial, atenda o pedido que lhe faço agora (peça a graça que deseja). Afugentai de nós a peste e os desassossegos. Possamos por Vosso intermédio obter a cura de todas as doenças, encontrar as portas do Céu abertas e sermos felizes por toda a eternidade. Amém.

Destaque-se ainda dessa prece as ações que se demanda da santa: rogar por, proteger (cobrir com o manto, desterrar males e maldições, afugentar a peste e o desassossego), atender ao pedido, intermediar a cura das doenças e a chegada às portas do céu. Nota-se nessa demanda de comportamento a presença da ambivalência que, em trabalhos anteriores, já havia assinalado quanto à figura do santo. Ele é ora o intermediário, ora o taumaturgo. Há também um jogo entre pedidos genéricos e um pedido concreto, determinado, que se quer alcançar no momento, quando se abre espaço para inserir o pedido do suplicante ("peça a graça que desejar").

Embora a doutrina oficial da Igreja aponte os santos como mediadores de graças, essa mesma hierarquia religiosa exige a comprovação de milagres no processo de canonização. O reconhecimento de que um santo é capaz de fazer milagres o mantém no domínio de quem pode agir como um taumaturgo, e não apenas como um mediador, um intercessor. É nesse horizonte, marcado por ambiguidades e por ambivalências, que a figura santa se inscreve.

Mas há orações mais disciplinadas, nas quais ortodoxamente o pedido é feito a Deus por intercessão de um santo; e primeiro se agradece para depois pedir, como podemos ver nessa oração a Santo Expedito:

Ó Deus nosso Pai, [começa o agradecimento:] nós vos agradecemos pelo exemplo de humildade e caridade que destes a santo Expedito, colocando-o sempre ao lado dos irmãos mais fracos e necessitados.[agora, o pedido:] Nós vos pedimos, ó Pai, que orienteis, com a vossa graça, todos os nossos pensamentos, palavras e ações. Que possamos também, com muita coragem, fidelidade e prontidão, ser fiéis aos nossos compromissos com a comunidade e com nossos irmãos mais carentes. Queremos ainda vos pedir, por intercessão de santo Expedito, que possamos vos servir, com toda a fidelidade, até os últimos dias de nossa vida (pode-se também fazer um pedido especial). Santo Expedito, rogai por nós! 
Assim, a oração envolve o reconhecimento das capacidades do santo, o enaltecimento de suas virtudes e a marcação intensa de assimetria entre quem fará um pedido e quem o atenderá. Esse formato, que insere o pedido em uma etiqueta que o torna adequado, da qual tratei em um artigo anterior (Menezes, 2004c), eufemisa o fato de que um santinho é também um suporte instrumental para a realização de pedidos eficazes a um santo; um modus operandi, uma espécie de receita que torna o ato de pedir discreto, suave, porque realizado no interior de determinados parâmetros que envolvem a disciplina, a obediência a uma sequência de regras e hierarquias relevantes ao catolicismo.

Há ainda em alguns santinhos descrições precisas dos procedimentos a serem seguidos para ver os pedidos atendidos. As ações necessárias incluem combinar a oração do santo a outras, usar velas, fazer gestos específicos como o sinal da cruz, etc.

Oração + pai nosso, ave Maria em 9 dias; Vela acesa durante oração; Oração + 7 Pai-Nosso, 7 Ave Maria e 1 Credo ao sagrado Coração de Jesus e pelas 7 dores de Maria Santíssima; Oração + 1 Pai -Nosso, 1 Ave Maria e fazer o sinal da Cruz; Oração. Reza-se 13 pais nossos e 13 ave-marias treze dias; Oração + 1 Pai nosso, 1 Ave-Maria e 1 Glória ao Pai; Oração + três pai nosso, três ave-maria e fazer o sinal da cruz; Oração +7 pai-nosso, 7 ave-maria e 1 credo ao Sagrado Coração de Jesus. (Orientações retiradas de vários santinhos diferentes).

Nessas "receitas" de oração, certos números parecem ter mais apelo do que outros $-1,3,7,9,13$. Talvez se possa pesquisar sua relação com a numerologia bíblica, e apostar numa "cultura bíblica" pervasiva, como fez Otávio Velho (1987) em seu artigo sobre a besta-fera.

Há também indicações sobre a situação ideal para usar a oração em questão, seguida da indicação da especialidade do santo:

Sempre que você se sentir só e impotente para resolver determinada situação e problema, seja de que ordem for, não se desespere. Rezando periodicamente a N. S. do Desterro, você conseguirá afastar Todos os Males Que Possam the Afligir.

Se você está com algum PROBLEMA FINANCEIRO de difícil solução, PEÇA AJUDA À SANTA EDWIGES. Esta Santa é a protetora dos Pobres e Endividados. (Grifo do texto original). 
Se você está com algum problema de difícil solução, precisa de ajuda urgente, peça esta ajuda a Santo Expedito, que é o Santo dos Negócios que precisam de Pronta Solução e cuja invocação nunca é tardia.

Conjugam-se, então, nos santinhos referências não apenas a um modo de dizer, mas também a um modo de fazer, ou melhor, a um modo específico de fazer o dizer. Não basta rezar a oração, é preciso fazê-lo em situações determinadas, de formas precisas, o que aponta para uma composição de fala, gesto e contextos. O santinho contem uma miniliturgia e indica que a prece deve ser uma performance, uma combinação de regra, costume e sentimentos postos em ação. Estamos, ao mesmo tempo, próximos do clássico de Marcel Mauss sobre a prece (Mauss, 1968), e da atual teoria da performance (associação também feita por Deremetz, 1994).

\section{A circulação dos santinhos}

No trabalho de campo no convento, os santinhos eram um dos suportes em que diversos santos e santas se faziam presentes no local, além de azulejos, quadros, estátuas em altares ou pedestais, medalhas, relevos. Mas, como já dito, eram suportes que chegavam prioritariamente pelas mãos de frequentadores, que os deixavam para distribuição gratuita, como forma de ex-voto.

Essa prática aponta para uma questão curiosa quanto à reprodutibilidade dos santinhos (e voltamos assim a formulações da abertura deste texto). Se eles são comprados aos milhares, e seu comprador geralmente o faz "por uma graça alcançada", com a obrigação de distribuí-los para divulgar a devoção, isso se torna um certo desafio: como encontrar mil, ou duas mil pessoas, para entregar os santinhos? A saída é deixá-los em lugares públicos, para que as pessoas os apanhem, notadamente no interior de templos católicos, mas também em lugares "inesperados": jornaleiros, lojas de flores, consultórios veterinários, peixarias, bancos de ônibus..$^{10} \mathrm{~A}$ reprodutibilidade massiva sem

\footnotetext{
${ }_{10}$ Os lugares citados para além de templos religiosos são pontos em que recolhi santinhos nos últimos meses. Segundo os responsáveis por esses estabelecimentos comerciais, são clientes que pedem para deixar os santinhos para os demais frequentadores pegarem.
} 
possibilidade de descarte gera uma infestação de santinhos por diversos pontos da cidade e permite a composição de panteões nos lugares mais inusitados. ${ }^{11} \mathrm{E}$ isso que ocorre no convento de Santo Antônio, e foi em nichos, bancos, altares laterais - numa periferia pouco controlada - que encontrei muitos santinhos.

No entanto, essa prática, longe de ser estimulada ou tolerada pelos responsáveis pelo local, é sistematicamente contida, pela retirada desse material por voluntárias que ajudam nas missas. Assim, se há uma certa facilidade na colocação de material - basta depositá-lo discretamente em um altar lateral - provavelmente ele será, pouco tempo depois, recolhido. Porém, apesar das retiradas sistemáticas, os santinhos continuavam a aparecer: 30 a 60 minutos depois de cada limpeza, lá estavam eles, novamente, numa espécie de movimento de ondas.

Isso me fez pensar numa luta surda, microscópica e cotidiana entre frequentadores e responsáveis pelo templo em torno de concepções de sagrado e de religião. Os santinhos revelam-se bons para pensar nas formas de apropriação (Certeau, 1990) do lugar por seus frequentadores, pois diferentemente das demais imagens, em suportes mais vistosos ou rígidos, não conseguem ser filtrados pelo crivo dos frades. Resta-nos buscar compreender o que está em jogo nesse vai e vem de santinhos.

Para muitos, esse material se qualifica como "comércio", "crendice", ignorância", "falsa religião". Uma pessoa que pede alguma coisa a um santo, oferecendo-lhe em troca determinada retribuição, estaria de fato comprando ou fazendo uma barganha pela concessão de benesses. As trocas simbólicas com os santos chegariam mesmo a ser condenadas como "comércio da salvação", ou "mercantilização da fé". Buscando os santinhos na internet, encontrei em vários sites debates sobre a adequação de se mandar imprimi-los. Além de comentários de evangélicos que condenavam essas práticas, por defenderem que a verdadeira e única intervenção é a de Jesus, para a qual inexistem mediadores, há também católicos que condenam os santinhos enquanto inutilidade: "é melhor doar dinheiro aos pobres; é melhor ajudar quem precisa, isso não serve para nada”.

11 Lembro aqui, quase como uma anedota, da portaria de serviço do Museu Nacional, onde todos os dias passamos professores, funcionários e alunos com modernos crachás de controle eletrônico, através de uma catraca, também eletrônica, que fica ao lado de uma série de santinhos, colados num suporte de madeira, sobre a mesa dos porteiros do museu. Pequenos panteões cotidianos, em certa medida aleatórios, mas quase onipresentes...

Horizontes Antropológicos, Porto Alegre, ano 17, n. 36, p. 43-65, jul./dez. 2011 
Essa crítica foi encontrada no convento. Em campo, ao coletar exemplares dos santinhos, levei um dia uma repreensão de uma senhora. Ela recomendou-me cuidado, que não usasse o santinho de qualquer maneira. Como e por quê? Segundo ela, eu deveria primeiro riscar atrás onde aparece escrito: "por uma graça alcançada, mandei imprimir 5.000 exemplares dessa oração". Por quê?

Porque passa uma ideia errada de que é preciso ter dinheiro para imprimir 5 mil cópias para conseguir uma graça do santo.

[Pergunta:] Por isso vocês retiram os santinhos?

É, nos levamos para as crianças do catecismo riscarem essa parte, depois fica pronto para usar, a gente deixa pegar.

A reprimenda da informante foi bastante instrutiva, pois colocou em pauta duas questões: a utilidade dos santinhos, que ficam prontos para usar, e todos os artifícios que são utilizados para que eles não sejam, simplesmente, descartados.

A utilidade: seria preciso indagar para que, enfim, serve um santinho e qual o seu possível uso. E antes de qualquer acusação de utilitarismo na análise, apresso-me em enfatizar que estou incorporando esse tema como uma questão nativa, pois os próprios envolvidos têm essa preocupação. Vimos até agora que há uma dimensão pedagógica, catequética, informativa, publicitária nesses compósitos. Vimos também que eles são ex-votos. Mas do ponto de vista de quem os recebe, ou de quem os pega nos ambientes em que são deixados, qual a sua utilidade?

Novamente na internet, encontrei em março de 2009 um debate no blog Santuário: "O que faço com os santinhos que recebo?" pergunta a blogueira. Resposta de outro internauta: "Use como marcador de livro, pode ser uma boa solução."

Em campo, outros usos apareceram: guardar na carteira como amuleto é algo bastante comum: molham-se os santinhos com a água benta aspergida pelos frades e depois, sacralizados, eles são guardados nos compartimentos donde irradiarão proteção.

Receber um santinho pode ser também um sinal: D. Nadir, uma frequentadora assídua do convento, relatou-me uma experimentação, à época recente, com Santo Expedito: 
Minha filha Célia queria trocar de emprego. Eu sou muito devota de Santo Antônio, mas resolvi experimentar Santo Expedito, porque eu dei uma esmola na saída do metrô, e a senhora me deu em troca um santinho de Santo Expedito, então resolvi experimentar. No quarto dia [depois que pediu], chegou um convite para minha filha fazer uma entrevista. Então mandei imprimir um milheiro [de santinhos], chegou pelo correio, estou indo no banco para pagar o boleto. Vou mandar os santinhos pro lugarejo da minha família, no interior do Ceará, pra minha prima distribuir [porque lá não tem dessas coisas].

O sinal de santo Expedito, mediado pela pessoa que lhe deu um santinho, motivou D. Nadir a experimentá-lo. Por sua vez, tendo conseguido a graça do santo, mandou imprimir seus santinhos em uma gráfica, distribuindo-os no Ceará, tornando-se ela também uma divulgadora da devoção entre "necessitados" de imagens impressas.

A busca por formas de usar os santinhos remete à preocupação de evitar o descarte: o que fazer com eles quando os recebemos? Podemos jogá-lo fora? Guardamos? Guardamos todos os que recebemos ou só alguns que nos são mais simpáticos, ou alguns pelos quais temos alguma devoção? Então, o que fazer para não jogá-los fora? Até mesmo os que condenam a impressão dos santinhos, como a senhora do convento que os retira, não se livram deles com facilidade: riscam as partes "erradas" e procuram reaproveitá-los.

Se há, efetivamente, uma tensão quanto a esse descarte, estaria ela relacionada a algum medo difuso do castigo divino, ou do castigo do santo, combinado a um interesse também difuso por formas de proteção que favorecem a prática de guardá-los? Poderíamos dizer, talvez, que, para aqueles que os guardam por considerar errado jogá-los fora, a sacralidade do compósito transcende a vulnerabilidade do suporte: para esses agentes, a reprodutibilidade da imagem sagrada não destrói sua aura, a coisa reproduzida guarda uma força que ultrapassa o material que a compõe. Mais do que uma representação, no sentido das teorias da comunicação e da arte, teríamos na imagem sagrada, como ressaltam outros autores, uma forma de presença e potência (Belting, 1998; Ginzburg, 2001a; Vernant, 1973, 1992). Estaríamos próximos a um processo de simbolização no qual, como diz Otávio Velho (1987, p. 13),

é como se por uma espécie de Carisma, algo do significado passasse para o significante, o que demandará na vida práticas ações concretas e ritualizações tendo-o como objeto. 
Lembro do livro de orações de minha avó paterna povoado de santinhos, mais do que marcadores em um livro, lembranças, isto é, marcas objetificadas de relações que povoaram sua vida. Lembro também de uma caixinha na mesa de cabeceira de minha mãe, em que os santinhos eram guardados junto a outros compósitos texto-imagem, inúteis e preciosos, como aqueles que anunciavam batismos, primeiras-comunhões e falecimentos. Mas essas evocações já apontam para uma outra etnografia, um outro conjunto de questões...

\section{Considerações finais}

Finalizando, e por tratar-se de um texto de certo caráter programático, gostaria de apontar para alguns possíveis desdobramentos do tema apresentado. Se entre as preocupações da antropologia atual estão, simultaneamente, a produção de análises que contemplem a vida social em sua dinâmica, em movimento; bem como o interesse pela vida social dos objetos, os santinhos, em sua circulação, podem se constituir num caso "bom para pensar" essas duas dimensões, associadas a outros temas relevantes, como religião, simbolismo e formas de sociabilidade.

Uma análise dos santinhos pode ainda nos levar a refinar teorias sociais sobre arte, representação, originalidade, as quais é preciso perceber se fazem sentido para as imagens religiosas. Por exemplo, é possível indagar se as noções de verdadeiro e falso, autêntico e inautêntico, aplicam-se aos santinhos e, caso se apliquem, poder-se-ia indagar também se os critérios usados para essas distinções seriam os mesmos que os utilizados nos domínios da arte, ou se seria preciso reconhecer-lhes uma lógica específica. E a noção de representação, aplicada às análises de símbolos, é significativa para pensar os santinhos? Eles representam o santo, ou o tornam presente em alguma medida?

Também é possível, através dos santinhos, perceber se e em que medida as teorias de valor, ou as discussões sobre mercadoria, são aplicáveis a objetos religiosos. Em sendo, seria possível indagar se a função-mercadoria dos objetos sagrados se combina à função religiosa, ou se ambas se ofuscam em alguma medida. Quanto à sacralidade, esses santinhos, produzidos em gráficas, são objetos religiosos desde sempre ou se tornam religiosos a partir de algum processo? Esses são exemplos de algumas das questões que poderiam ser desenvolvidas na continuidade de uma análise antropológica sobre os santinhos. 
O que ressalto é que eles já apareceram aqui como elementos capazes de constituir uma cadeia, em que o receptor de hoje se torna o doador de amanhã, a qual potencialmente está sempre agregando novas pessoas. Isso significa que, se a forma tradicional das ciências sociais pensarem a relação santo-devoto foi o modelo da díade, isto é, da relação diádica, os santinhos nos facilitam "pensá-la em rede", uma rede que sua circulação ajuda a construir e/ou a ativar. Como propõem Roberto Orsi (2005) e William Christian Jr. (1991), acredito que seja preciso assumir a ideia da religião como uma rede de relações e interações envolvendo o céu e a terra, ligando pessoas, santos, anjos, demais personagens da esfera celeste e a própria Trindade. E incluir nessas redes, também, as coisas, os elementos da cultura material, dentre as quais os santinhos, sejam como mediadoras dessas ligações, sejam como seus agentes efetivos.

\section{Referências}

APPADURAI, A. (Org.). The social life of things: commodities in cultural perspective. Cambridge: Cambridge University Press, 1990.

BELTING, H. Image et culte: une histoire de l'art avant l'époque de l'art. Paris: Cerf, 1998.

BELTING, H. La vrai image: croire aux images? Paris: Gallimard, 2007.

BENJAMIN, W. A obra de arte na era de sua reprodutibilidade técnica. In: BENJAMIN, W. Obras escolhidas: magia e técnica, arte e política. 7. ed. São Paulo: Brasiliense: 1994. p. 165-196.

CALCOGRAFIA. Enciclopédia Itaú Cultural de Artes Visuais, 2010. Disponível em: <http://www.itaucultural.org.br/aplicexternas/enciclopedia_ic/index. $\mathrm{cfm}$ ?fuseaction $=$ termos_texto\&cd_verbete $=35>$. Acesso em: 21 ago. 2010.

CERTEAU, M. de. L'invention du quotidien: I - Art de faire. Paris: Gallimard, 1990.

CHRISTIAN Jr., W. A. Secular and religious responses to a child's potentially fatal illness. In: WOLF, E. (Ed.). Religious regimes and state-formation: perspectives from European ethnology. Albany: State University of New York, 1991. p. 163-180. 
CLAVERIE, E. La Vierge, le désordre, la critique. les apparitions de la Vierge à l'âge de la science. Terrain, n. 14, p. 60-75, 1990.

DEREMETZ, A. La prière en représentation à Rome: de Mauss à la pragmatique contemporaine. Revue de l'Histoire des Religions, anée CCXI, n. 2, p. 141-165, avril/juin 1994.

FOUCAULT, M. A verdade e as formas jurídicas. Rio de Janeiro: PUC/NAU, 1996.

FERGUSON, G. Signs \& simbols in Christian art. New York: Oxford University Press, 1981.

FREEDBERG, D. El poder de las imágenes: estúdios sobre la historia y la teoria de la respuesta. Madrid: Cátedra, 1992.

GINZBURG, C. Representação: a idéia, a palavra, a coisa. In: GINZBURG, C. Olhos de madeira: nove reflexões sobre a distância. São Paulo: Companhia das Letras, 2001a. p. 85-121.

GINZBURG, C. Ecce. Sobre as raízes culturais da imagem de culto cristã. In: GINZBURG, C. Olhos de madeira: nove reflexões sobre a distância. São Paulo: Companhia das Letras, 2001b. p. 250-264.

GRUZINSKI, S. A guerra das imagens: de Cristóvão Colombo a Blade Runner (1492-2019). São Paulo: Companhia das Letras, 2004.

HERZFELD, M. Icons and identity: religious orthodoxy and social practice in rural Crete. Anthropological Quaterly, v. 63, n. 3, p. 109-121, July, 1990.

JOLLES, A. A legenda. In: JOLLES, A. Formas simples. São Paulo: Cultrix, 1976. p. 30-59.

KEANE, W. Religious language. Annual Review of Anthropology, n. 26, p. 47-71, 1997.

KOPYTOFF, I. The cultural biography of things: commodization as process. In: APPADURAI, A. The social life of things: commodities in cultural perspective. Cambridge: Cambridge University Press, 1990. p. 64-91. 
LITOGRAFIA. Enciclopédia Itaú Cultural de Artes Visuais, 2010. Disponível em: <http://www.itaucultural.org.br/aplicexternas/enciclopedia_ic/ index.cfm?fuseaction $=$ termos_texto\&cd_verbete $=5086 \& 1$ st_palavras $=\& c d$ idioma $=28555 \&$ cd_item $=8>$. Acesso em: 21 ago. 2010.

MAUSS, M. La prière. In: MAUSS, M. Oeuvres: v. 1. Paris: Minuit, 1968. p. 357-477.

MENEZES, R. de C. A dinâmica do sagrado: um estudo antropológico de um santuário católico no Rio de Janeiro. Tese (Doutorado em Antropologia Social)-Museu Nacional/Universidade Federal do Rio de Janeiro, Rio de Janeiro, 2004a.

MENEZES, R. de C. A dinâmica do sagrado: rituais, sociabilidade e santidade num convento do Rio de Janeiro. Rio de Janeiro: Relume-Dumará, 2004b.

MENEZES, R. de C. Saber pedir: a etiqueta do pedido aos santos. Religião e Sociedade, ano 24, n. 1, p. 46-64, 2004c.

MENEZES, R. de C. Uma visita ao catolicismo brasileiro contemporâneo: a bênção de Santo Antônio num convento carioca. Revista da USP, n. 67, p. 24-35, 2005.

MENEZES, R. de C. Santo Antônio no Rio de Janeiro: dimensões da santidade e da devoção In: TEIXEIRA, F.; MENEZES, R. de C. Catolicismo plural: dinâmicas contemporâneas. Petrópolis: Vozes, 2009. p. 109-133.

O'NEIL, J. Saints, devotion to the. In: [THE] CATHOLIC UNIVERSITY OF AMERICA. The new Catholic Encyclopedia. New York: McGrawn \& Hill, 1968. v. 12, p. 962-963.

ORSI, R. A. Between heaven and earth: the religious worlds people make and the scholars who study them. Princeton: Princeton University Press, 2005.

TURNER, V. Iconophily and iconoclasm in Marian pilgrimage. In: TURNER, V.; TURNER, E. Image and pilgrimage in Christian culture: anthropologial perspectives. Oxford: Basil Blackwell, 1978. p. 140-171. 
VELHO, O. O cativeiro da besta-fera. Religião \& Sociedade, ano 14, n. 1, p. 4-27, 1987.

VERNANT, J.-P. A categoria psicológica do "duplo". In: VERNANT, J.-P. Mito e pensamento entre os gregos. São Paulo: Difel; Edusp, 1973. p. 263-276.

VERNANT, J.-P. Figuração e imagem. Revista de Antropologia, v. 35, p. 113-128, 1992.

XILOGRAFIA/XILOGRAVURA. Bricolagem, 2007. Disponível em: $<$ http:// bricolagem.wordpress.com/2007/05/21/artesanato-arte-xilografia/>. Acesso em: 21 ago. 2010. 